\title{
GREETINGS FROM NOVÉ ZÁMKY - 40 YEARS OF TEXTILE RESEARCH IN SLOVAKIA ${ }^{1}$
}

\author{
TEREZA ŠTOLCOVÁ ${ }^{(1)}$ - J URAJ ZAJONC ${ }^{(0)}$ \\ K A R I N A GR ÖM E R (i)
}

\begin{abstract}
This article briefly presents the history of textile archaeology in Slovakia, the foundations of which were laid out by Karol Pieta. With his scientific curiosity and hunger for the new adventures, Karol Pieta has been crossing the boundaries of his discipline his whole life. The conditions for the preservation of organic materials are generally very unfavourable, which is why they were often overlooked by archaeologists. Interest for textiles first started with remains hidden in tubular anklets dated to the La Tène Period, initially noticed and studied by Karol Pieta. The most unique ones come from Nové Zámky and shed light on an embroidery technique of the Late Iron Age. The majority of prehistoric textiles in Slovakia are dated to the La Tène Period and it is comparable with finds from the Czech Republic and Austria. A find from an unknown location analysed in 2021, can with certainty be assigned to the corpus of La Tène Period textiles. It can be assumed that linen tabbies made of simple z-spun threads were preferred in this period. Textiles were found in different circumstances, usually mineralised on metal artefacts in graves. The primary use of these textiles was for clothing and ritual wrappings. A secondary use is evidenced by textile fillings of bronze hollow anklets. A Celtic female dress was reconstructed based on the position of artefacts found in the graves, as well on the observations of La Tène Period textiles, in particular the Nové Zámky embroidery. It is interesting to see, that textiles were apparently used as a code to reflect social and aesthetic values. In society they played an important role in the definition and expression of social space and of group relations.
\end{abstract}

Keywords: Slovakia, La Tène Period, textiles, reconstruction of dress, visual coding.

\section{INTRODUCTION}

Karol Pieta's research interests are varied, one of them being textile archaeology. His $80^{\text {th }}$ birthday gives us therefore an opportunity to make a connection between him and our interest for archaeological textiles. Tereza Štolcová (formerly Belanová) started working on archaeological textiles during her doctoral thesis in 2003 when Karol Pieta was her supervisor at the Institute of Archaeology of the Slovak Academy of Sciences (Štolcová 2010). He directed her to the La Tène Period textiles from the territory of Slovakia and Moravia (Belanová 2005a; 2005b), which later became a part of a broader Europe-wide research on textiles (Belanová-Štolcová 2012). Tereza enthusiastically took over Karol's work, which he started in the early 80s. Thanks to his wide network of specialists abroad, she got in touch with some of the leading textile experts in archaeology, like Lise Bender Jørgensen or John Peter Wild.

Cooperation with a wide range of researchers from in- and outside Slovakia has always been a main task in Karol Pieta's scientific life - empowered by his cordial character, his scientific curiosity and wish to share the new knowledge. The work on archaeological textiles that emerged from sites in Slovakia could only be done in studying and comparing contemporary finds in a wider geographical area (Pieta 1992). This especially applies to the Iron Age, where Slovak sites are embedded into wider cultural frameworks such as Hallstatt and La Tène cultures. Karol Pieta developed contacts with colleagues working on textiles from Austria, starting with Hans-Jürgen Hundt, who was active until the 1980's in the studies of textiles from the salt mines in Hallstatt and Dürrnberg (Hundt 1961; 1987), as well as Hallstatt and La Tène Period graves (Hundt 1974). With the fall of the Iron Curtain, Karol Pieta's contacts with Austria and its research institutions have been reinforced, with broader possibilities for personal travels and contacts in which the Natural History Museum Vienna (NHM) has played a central role. At the conference on Iron Age textiles organised by the NHM Vienna at Hallstatt in 2004 (Bichler et al. 2005), Karina Grömer got into contact with Karol Pieta and Tereza Štolcová. Since then, a fruitful cooperation led to shared presentations and publications as Iron Age textile technology from Austria and Slovakia (Belanová-ŠtolcoválGrömer 2009). The work on the wider geographical area

\footnotetext{
1 The study was realised within the VEGA project No. 2/0001/18 'Slovakia and the Middle Danube Region: Development from the Early history to the Early Middle Ages'.
} 
of Central Europe and its eastern part leads to interesting new insights into textiles as important factors for economic, technological and even social developments.

Last but not least it is important to mention Karol Pieta's overlap of his discipline, which he also utilised as one of the pioneers of experimental archaeology in Slovakia at e.g. the late Iron Age settlement Havránok at Liptovská Mara. Tereza Štolcová together with the ethnologist Juraj Zajonc used his work (Pieta 1996; 1999), knowledge and unpublished documentation when reconstructing the warp-weighted loom from the La Tène Period (Belanová/HarmadyoválZajonc 2005) and the Hallstatt Period (ŠtolcoválZajonc 2014; 2015). Around 1983/1984, Juraj Zajonc, as a first year student at the Faculty of Arts, Comenius University in Bratislava, visited Darina Bialeková at the Institute of Archaeology of the SAS in Nitra to consult spindle whorls for a student project. She pointed out to Juraj that one of her colleagues has been working on textile fragments recovered from bronze anklets. In fact, these were the famous textile fragments from Nové Zámky. They stuck in Juraj's mind as strips of tabby weave mounted in between the glass plates, the appearance of which did not interest him much. Two years later he realized they were an important discovery in the history of textiles, when he saw one of the fragments on the cover of the book 'The Beginnings of Clothing in Slovakia' (Furmánek/ Pieta 1985). He learned from it that the holes of the needle punctures in the fabric are unique evidence of decoration embroidered on a La Tène Period textile. He made a sketch of this motif in which he reconstructed the embroidery. Juraj Zajonc had no idea that this was his first, but not last encounter with this unique textile, which lead him to the man who discovered it (BelanoválBirkušoválZajonc 2005).

\section{LA TÈNE PERIOD TEXTILES IN SLOVAKIA AND MORAVIA IN CONTEXT}

The majority of prehistoric textiles in Slovakia are dated to the La Tène Period (Belanová 2005a; Belanová-Štolcová 2012; Bender Jørgensen 1992; 2005; Pieta 1992). Most of these finds come from the pe-

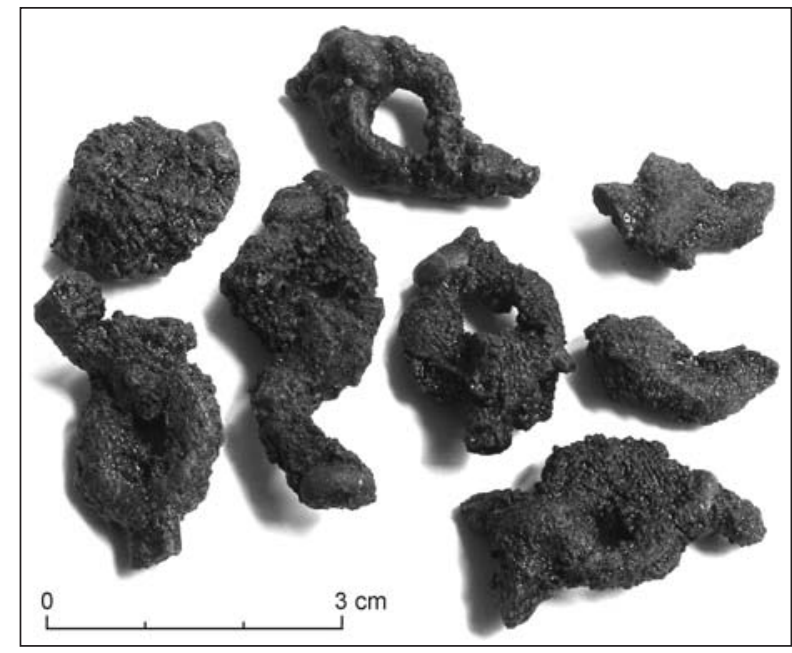

Fig. 1. Vel'ká Maňa, Nové Zámky distr. Inhumation grave 42/53. Fragments of an iron belt with mineralised tabby fabric (photo T. Štolcová).

riods LTB1, B2 and C1 (380-180 BC), known in the Middle Danube region as the so-called horizon of the flat Celtic inhumation graves (Bujna 2004, 321). The conditions for the preservation of organic materials are generally very unfavourable in this territory and archaeologists have thus tended to overlook such finds. All these textiles were found mineralised on metal objects in graves, where any organic matter was replaced by metal salts (Fig. 1-4). In a wider area north of the Middle Danube, i.e. the territory of the Czech and Slovak Republics, textiles dated to the La Tène Period are generally represented by corroded fragments adherent to metal objects like swords, shields, scabbards, lance-, spear- and arrowheads, knives, fibulae, anklets or belt rings. The primary use of these textiles is for clothing and ritual wrappings. A significant group of finds of secondary use is presented by bronze hollow anklets filled with textiles. Graves situated in the modern south-west Slovakia and Moravia - south-eastern part of the Czech Republic, have been analysed and/ or revisited in the past two decades (Belanová 2005a; 2005b; Belanová-Štolcová 2009; 2012; Štolcová 2011; 2013; 2019). ${ }^{2}$ They show similar characteristics and therefore are summarised in this article as one corpus of finds. Mineralised fragments consist of either simple tabbies or $2 / 1$ and $2 / 2$ twills, predominantly

\footnotetext{
2 Sites in south-west Slovakia: Bučany-Kopanice (Trnava distr.); Hurbanovo-Abadomb, Bacherov Majer, Chotín VIII, X-Horná lanová zem, Malé Kosihy-Horné Konopnice, Svätý Peter (Komárno distr.); Kamenín-Kisvölgy, Malá n. Hronom-Rövid Föld, Nové Zámky-Slovlik, Palárikovo-Dolný Keresztúr, Vel'ká Maňa (Nové Zámky distr.); Trnovec n. Váhom-Horný Jatov (Šala distr.). Sites in south-eastern part of Czech Republic (Moravia): Blučina-Konopné zahrádky, Telnice-Cihelna Mrkvicova, Bedřichovice (Brno-venkov distr.); Brno-Maloměřice, Plíže; Brno-Židenice, Táborská ulice (Brno-město); Břeclav-Na Zvolencích, Hustopeče-Šibenky, Mušov-U Propustě, Sedlec-škola (Břeclav distr.); Bučovice-Lišky, Holubice-Dílce, Křenovice-Přední díl, Nížkovice-Záhumenice, Slavkov u Brna-Povětrníky, Marefy-U Lišek (Vyškov distr.); Miroslav-Nám. Svobody 3 (Znojmo distr.); Svatobořice-Mistřín, Trávniky (Hodonín distr.); Postoupky-Hradisko (Kroměříž distr.). Textiles from the remaining part of Czech Republic (Bohemia) are listed in Belanová-Štolcová 2012, pl. 15: 4, c.f. further bibliography.
} 


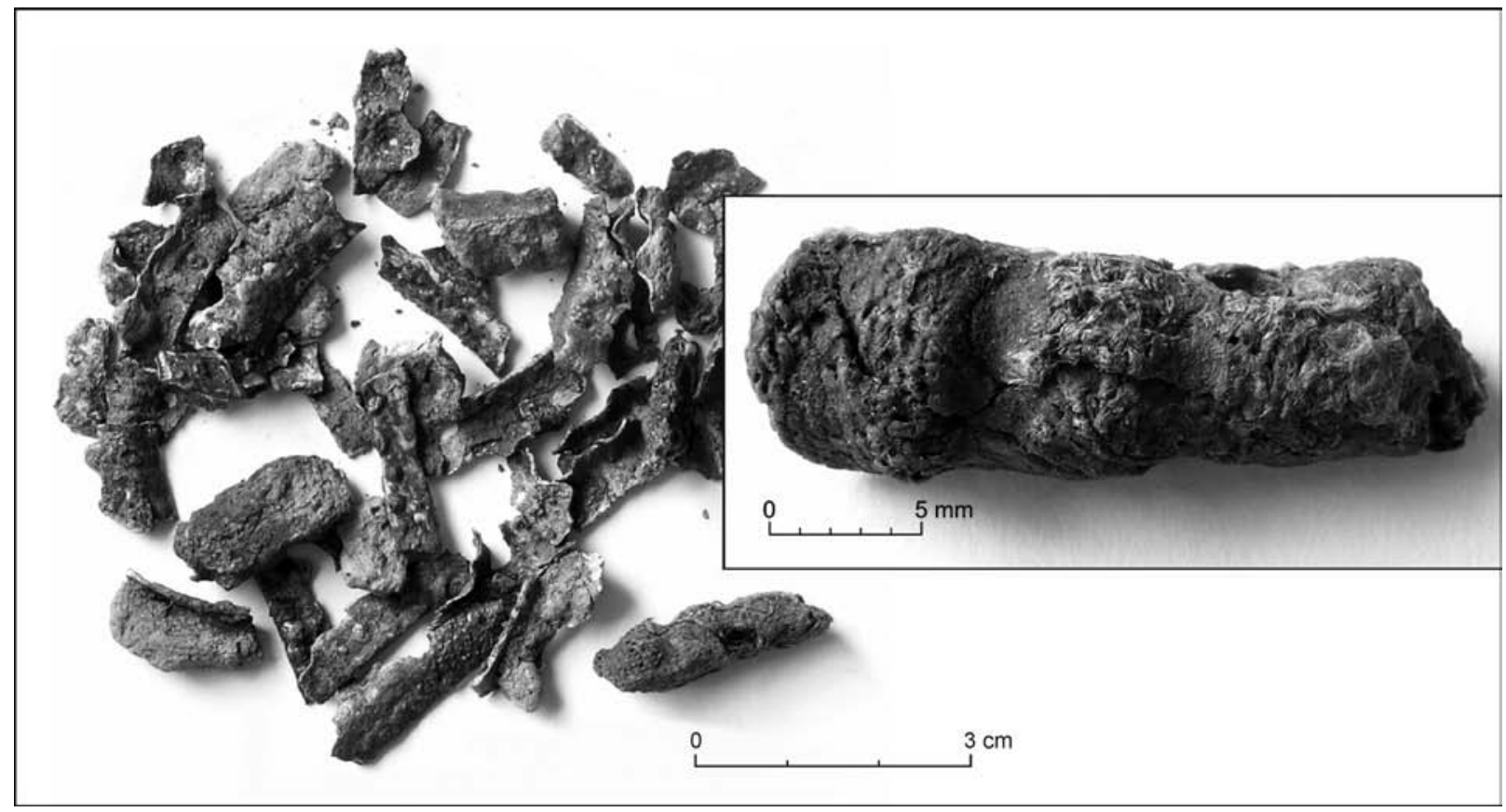

Fig. 2. Palárikovo, Nové Zámky distr. Inhumation grave 58/72. Fragmented bronze anklet and a detail of a textile plug found in one of the ends of the anklet. Tabby weave with z-twisted threads (photo T. Štolcová).

made of z/z-spun single threads with some exceptions of $S 2 z / z, z / S$ or $z / s$ twisted yarns. The thread count varies from very coarse ones with $4-8 \mathrm{~cm}$ in both systems, up to 28 threads in $1 \mathrm{~cm}$. Very finely woven textiles come almost exclusively from the filling of the tubular bronze anklets. Most of the determinable material was identified as flax, which is caused not only by a preference for linen textiles, but unfortunately also the mode of preservation and the state of research. Apart from the unique find of Nové Zámky with traces of embroidery, discussed below, La Tène Period textiles from the territory of Slovak and Czech Republic lack any information about sewing techniques, starting borders, and decoration or colour. However, the fragments of textiles twisted tightly inside tubular anklets provide other insights into textile manufacturing and use. Thus, it is quite demanding to say anything more about the function of mineralised textiles. In some cases, different weaves are present on a metal object in several layers, which indicates the use of several garment types or the way how it was worn. It may be concluded that coarser (woollen) fabrics are identified as upper garments and the finer ones are mostly linen, being part of an undergarment of the deceased (Belanová-Štolcová 2012, 320; Bender Jørgensen 1992, 49). Textiles were also used as parts of ritual wrappings of individual artefacts in grave (weapons or tools), or they might be recycled as fillings in anklets.

\section{THE ISSUE OF TUBULAR ANKLETS}

Bronze tubular anklets are a typical jewellery deposited in pairs in female inhumation graves and are commonly dated to the Old and Middle La Tène Period (stages LTB1b up to LTB2/LTC1), i.e. to the second quarter of the $4^{\text {th }}$ up to the first half of the $3^{\text {rd }}$ c. BC (Bujna 2004, 321; 2005, 140-149). In this context, a type with transversely ribbed hoop and moulded decoration of triple protuberances and the so-called caterpillar type are the most important ones (after Bujna 2005, fig. 16: type BR-C1, BR-C2, BR-C3 and BR-C4). They occur across the eastern area of Austria through Transdanubia and in the whole Carpathian Basin (Bujna 2005, 147). Apart from materials like fine clay or sand, they are usually filled with firmly twisted pieces of textile. Since these are usually very well preserved, they are the best source of information about textiles in the Late Iron Age from this area. However, they came to light only in the 80's when Karol Pieta studied them in detail (Pieta 1992). Textile fillings most likely served a role in the production process of the anklet (Hundt 1978, 622; Kostelníková 2002, 325; Müllauer/Ramsl 2007; Pieta 1992, 56).

From the territory of south-west Slovakia, twisted textiles that were found in tubular anklets are known from Hurbanovo (grave 11/80), Nové Zámky (grave 9), Palárikovo (grave 1/69, 15/70, 43/71, 50/71, 53/71, 58/72), Svätý Peter (grave 55, 58), 


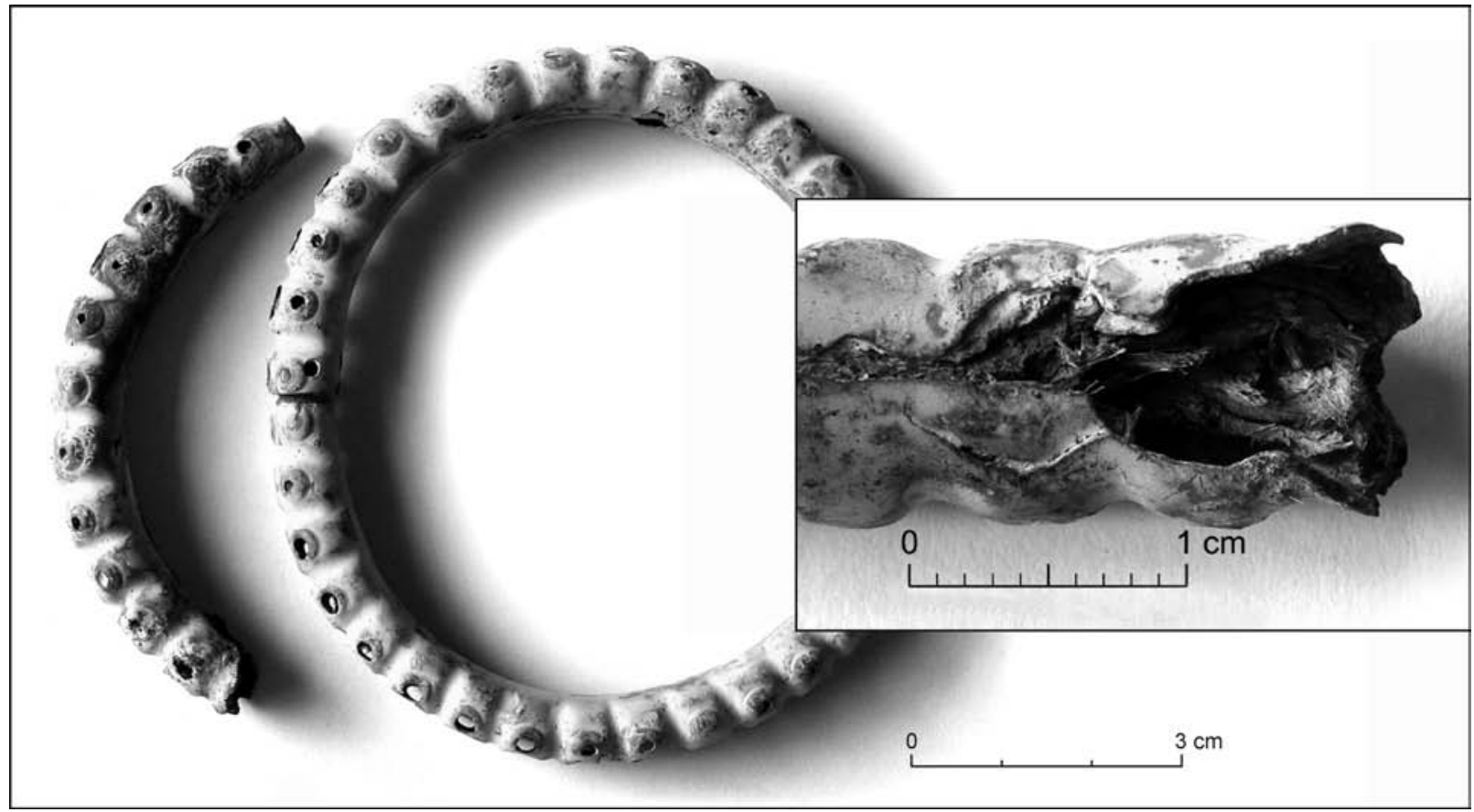

Fig. 3. Vel'ká Maňa, Nové Zámky distr. Inhumation grave 113/54. S2z-plied and $0.8 \mathrm{~cm}$ thick cord placed in a bronze anklet (photo T. Štolcová).

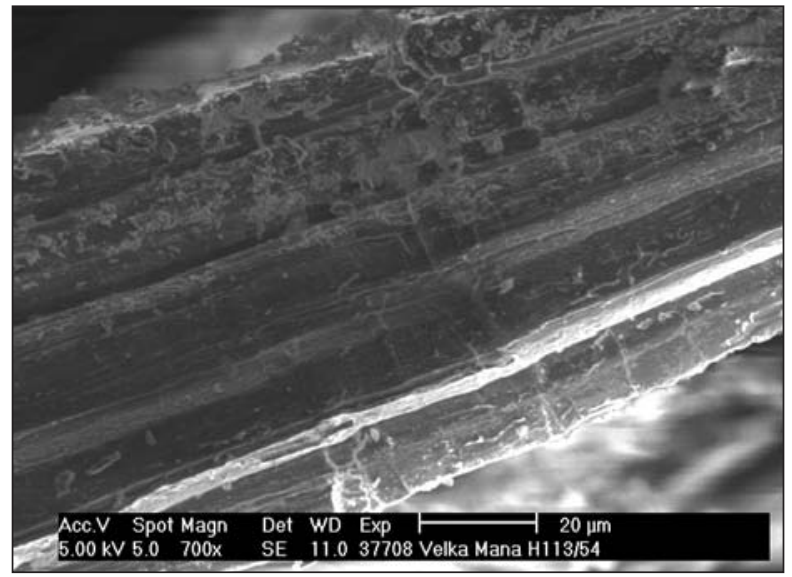

Fig. 4. Vel'ká Maňa. Nové Zámky distr. Inhumation grave 113/54. Detail of linen fibres from the cord placed in a bronze anklet (photo T. Štolcová).

Trnovec and Váhom (grave 233, 234), Vel'ká Maňa (grave 104, 113, 116, 129). ${ }^{3}$ In some of these anklets, textiles were found in the closing ends in a form of plug (Fig. 2). Some had just a thick twisted cord (Fig. 3; 4), however, most of the fabrics had a very fine quality with $\mathrm{z} / \mathrm{z}$ twist direction, thickness of thread between $0.3 \mathrm{~mm}$ to $0.8 \mathrm{~mm}$ and a thread count ranging from 7 up to 28 threads per $\mathrm{cm}$. Similarly, Moravian sites showed the same features of textiles retrieved from the tubular anklets: BrnoMaloměřice (Belanová 2005b), Miroslav and Mušov (Kostelníková 2002), Nížkovice (Štolcová 2013) and Bedřichovice (Štolcová 2019). In all cases, the flax fibre was dominant, in some cases hemp was also detected (Belanová-Štolcová 2012, 314, 319). There are parallel finds in Austria, such as Early La Tène anklets from Schrattenberg filled with textiles (Grömer et al. 2019) or from Mannersdorf am Leithagebirge (Müllauer/Ramsl 2007).

\section{ALL ROADS LEAD TO NOVÉ ZÁMKY}

None of the above mentioned textiles showed such special features like the find from Nové Zámky (Pieta 1992; Furmánek/Pieta 1985, 52-55) and was cited all over the Europe (e.g. Banck-Burgess 1999, 60; Grömer 2016, 203, 204) or used in dress reconstructions (e.g. Wilson 2017-2018, 37). Five fragmented fabrics come from a pair of tubular anklets dated to the LTB2 and belonged to the grave goods of a young female buried at a small Celtic graveyard (Pieta 1992, 54). She wore two bronze arm rings and one sapropel ring on her wrists, two hollow anklets on her ankles, two silver rings on the fingers of her left hand. Her garment was fastened by one bronze fibula under her chin and the other one on her right

\footnotetext{
3 Further details on these finds, catalogue of finds and bibliography in Belanová-Štolcová 2012, 321, 322, pl. 15: 2.
} 


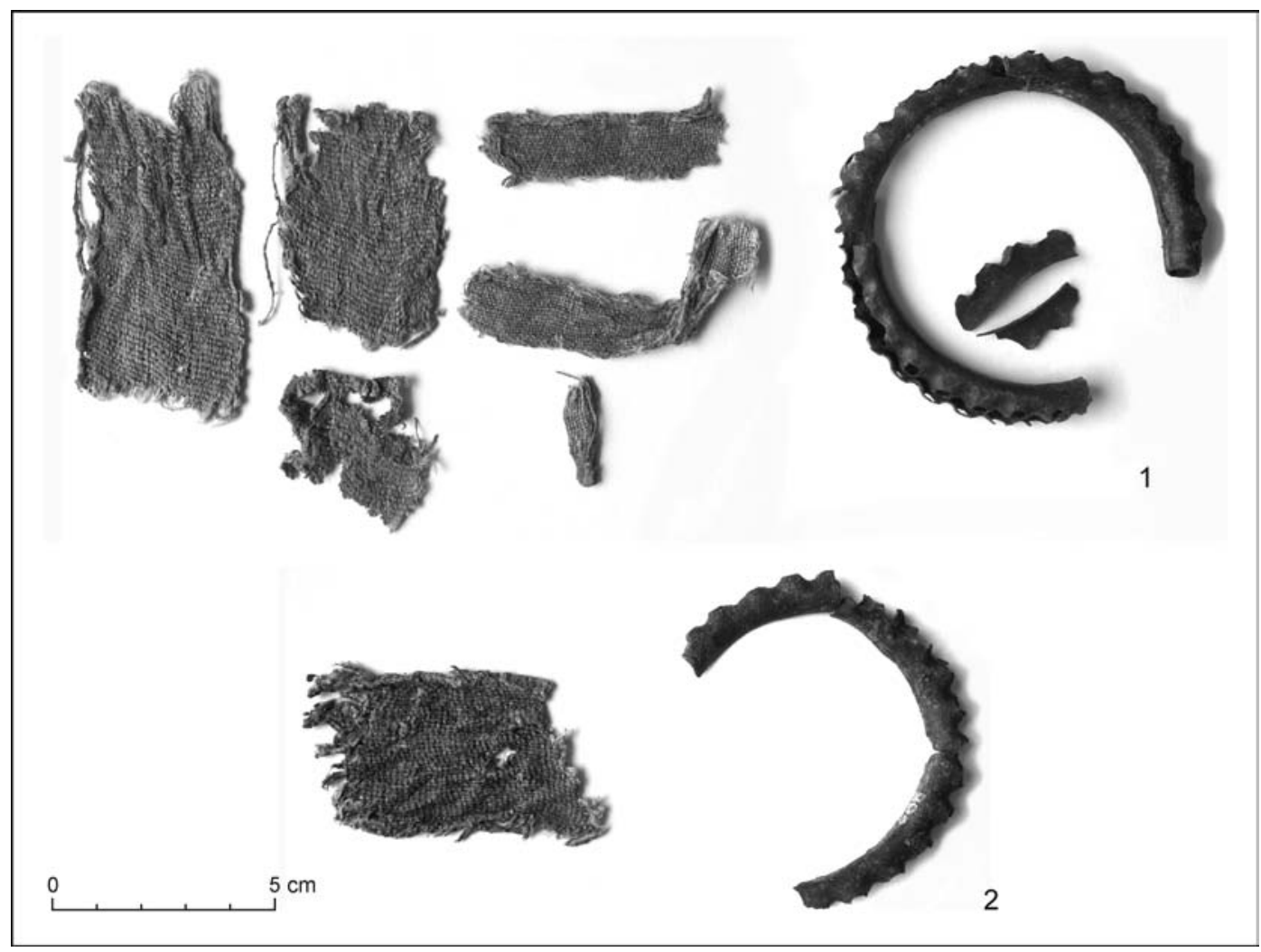

Fig. 5. Textiles recovered from the La Tène Period anklets. Inhumation grave, unknown location. 1 - no. 387; 2 - no. 388 (photo T. Štolcová).

shoulder. Two other fibulae were found on the right side of the body, as well as two ceramic pots. Three rings on her right side made of bronze sheet suggest a belt. Bronze tweezers could have been originally placed in a pocket that was attached to the belt (Pieta 1992, 55, 56).

All five fragments are made of a linen tabby, with $0.3-0.8 \mathrm{~mm}$ thick and $\mathrm{z}$-spun threads in both directions. The thread count was about 20-24 threads in warp and 12-14 threads in weft. Initial analyses have shown that these pieces were originally embroidered with a red woollen thread (Pieta 1992, 57). However, years later it was not possible to identify this thread anymore (Belanová 2005a, 180). Karol Pieta could prove that fragment no. 1 and 5 belonged originally together and were embroidered by a running stitch. He identified the composition of the pattern as two plaited stripes with S-motifs and trumpets in a form of horn of plenty (Pieta 1992, 57). The edge of fragments no. 1 and 5 was finished with an overcast stitch. The other three fragments also bear the stitch holes of embroidery but did not show such an intricate design. Pattern on the fragment no. 2 consists of a strip of diagonal flat S-curves with a widened upper part. The lower part of this pattern was not preserved. On fragment no. 3 cutting traces were identified. Besides a running-dog or a trumpet-like pattern, it also showed a similar pattern to fragment no. 2. Fragment no. 4 has a pattern in a form of diagonal lines, similarly to no. 2 and 3. Fragment no. 2 and 4 also shows some traces of mending (Pieta 1992, 57-60).

Twenty years have passed since the publication of 'The Beginnings of Clothing in Slovakia', when Tereza Štolcová encouraged Juraj Zajonc to look at the unique Nové Zámky finds again, this time with an ethno-archaeological approach. When considering the reinterpretation of its embroidery, ${ }^{4}$ it became clear that it is not only a unique example of this type of La Tène decoration, but also of contemporary ornamental Waldalgesheim style on a textile product. Karol Pieta reconstructed the pattern by following the irregularities as seen on the original pieces. The goal of our work was to make an ideal reconstruction of the fragment no. 1. The embroidery was copied to a paper by putting fine pins through the stitch holes in their direction. It showed that the embroidery was initially respecting the motifs, not the

\footnotetext{
4 Original interpretation published in Pieta 1992 was updated in Belanová/BirkušoválZajonc 2005.
} 

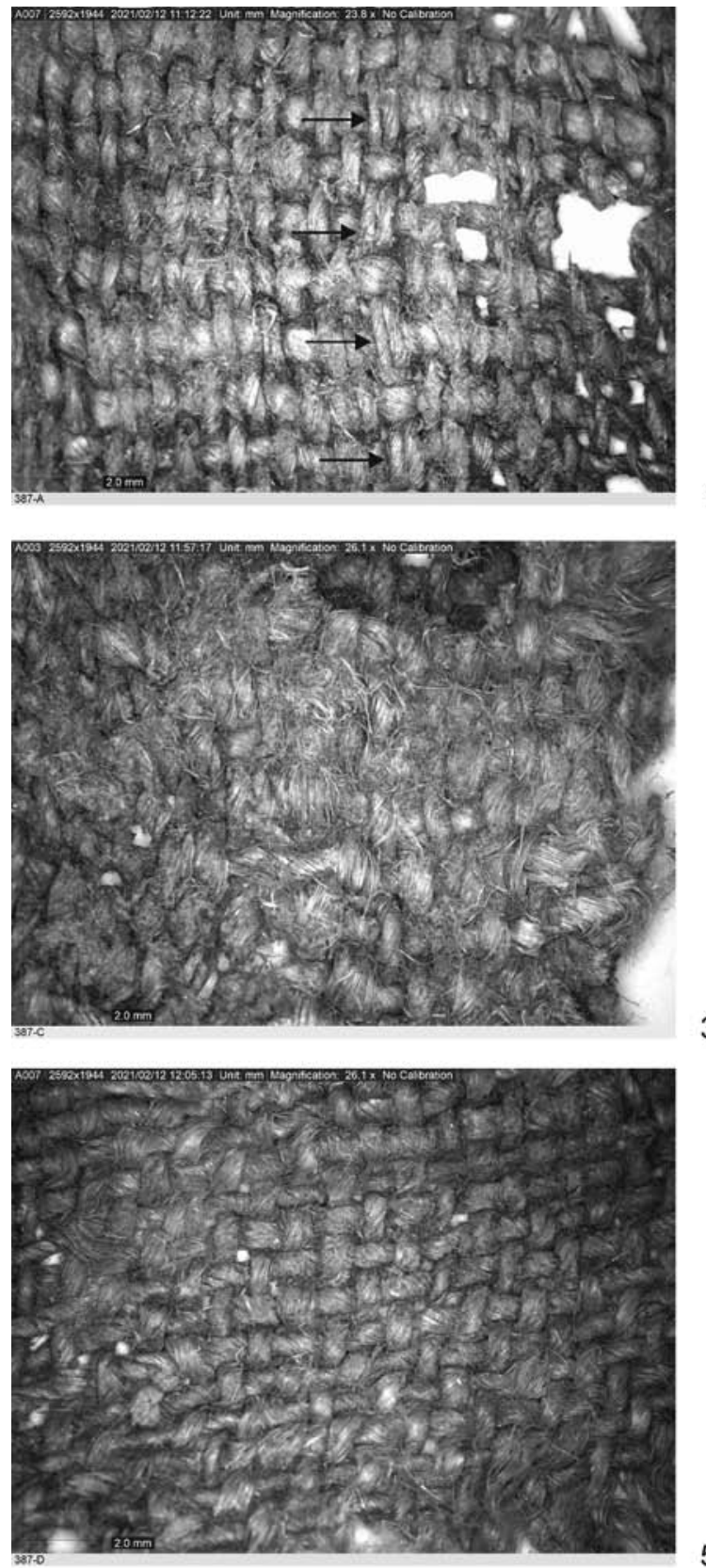

5

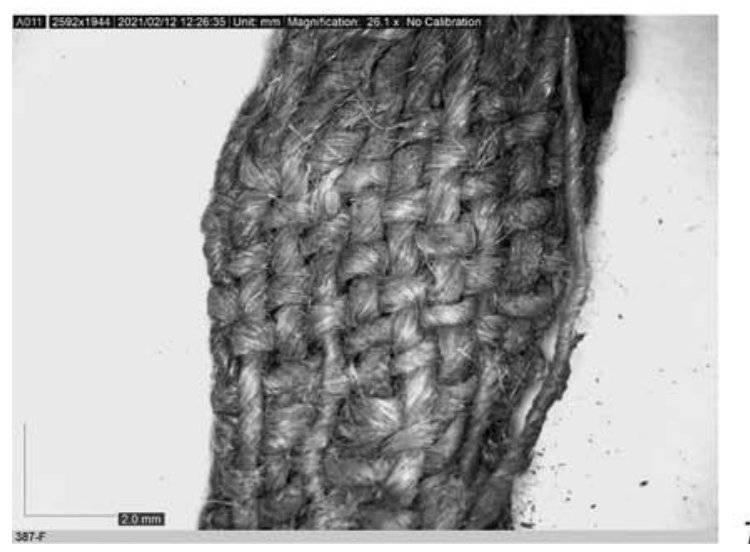

7

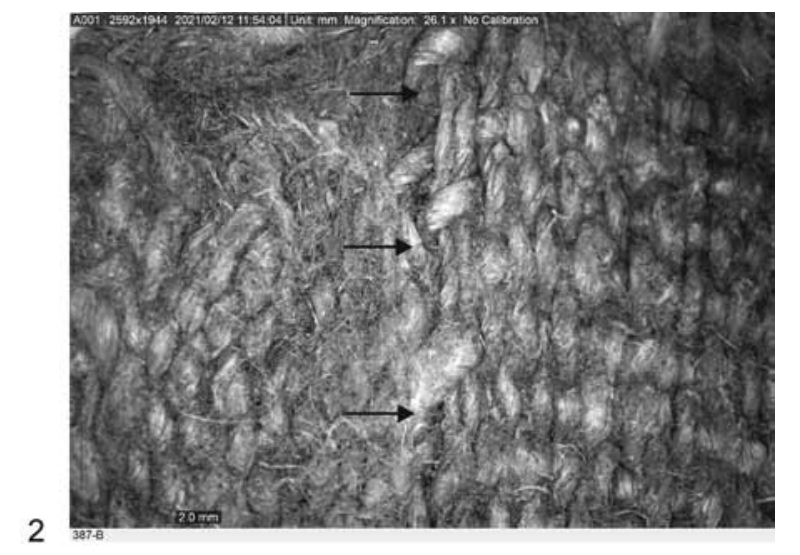

.
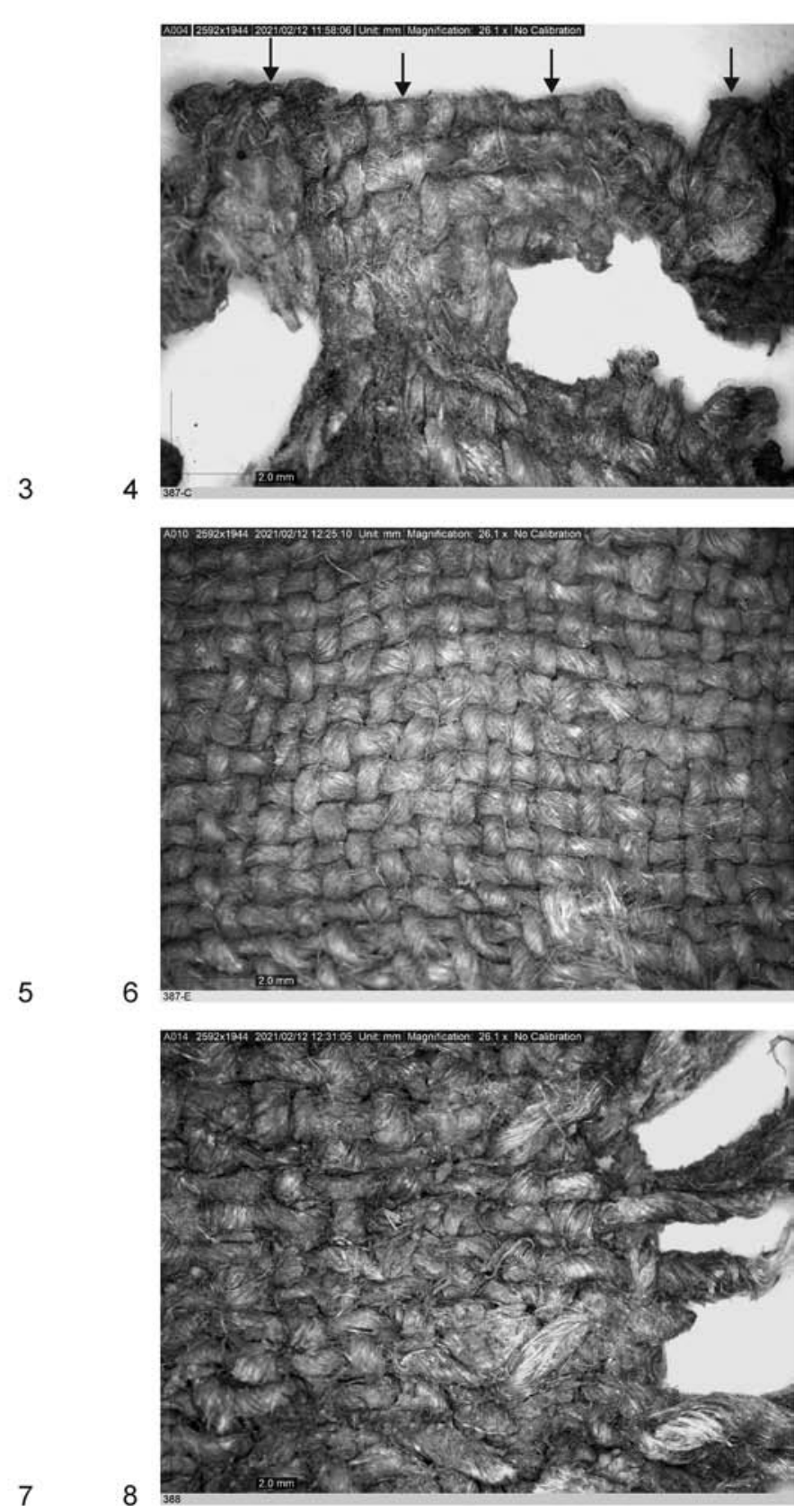

Fig. 6. Microscopic photos of the Fig. 5: 1-7 - textiles from anklet no. 387; 8 - textile from anklet no. 388; 1, 2 - arrows showing a double thread; 4 - arrows showing traces after cutting (photo T. Štolcová). 
rows in the fabric. By redrawing it onto a squared paper, the design was schematised. We started with a spatial interpretation of the composition: two intersecting bands forming a double-threaded motif. For each band, one can see the reverse and obverse with positive and negative alternating S-motifs. This way, the former interpretation of Karol Pieta was slightly corrected, as we consider the element of horn of plenty only as a part of the surface of the bands with S-motifs. Also, from the practical point of view, we corrected the running stitch to a satin stitch, which would be more plausible to use in creating such a composite design (Belanová/Birkušovál Zajonc 2005, 128-130).

\section{NEW FINDS OF UNKNOWN LOCATION}

Above all, an unpublished find of unknown origin was discovered in the archives of the Institute of Archaeology of the SAS and recently analysed by Tereza Štolcová. We would like to dedicate this analysis to Karol Pieta. Unfortunately, it does not contain any information about the site or dating. It consists of a pair of fragmented anklets with transversely ribbed hoop and moulded decoration of triple protuberances (Fig. 5).

An anklet with assigned no. 387 (Fig. 5: 1) contained six fragments and no. 388 (Fig. 5: 2) one fragment of a textile. The size of the first group is $\mathrm{A}-39 \times 81, \mathrm{~B}-57 \times 39, \mathrm{C}-38 \times 31, \mathrm{D}-55 \times 16$, $\mathrm{E}-78 \times 16, \mathrm{~F}-24 \times 6 \mathrm{~mm}$ and the second it is $60 \times$ $36 \mathrm{~mm}$. All of them are simple linen tabbies with z-spun threads in both systems (Fig. 6). Pieces A-C from find no. 387 belonged together. The thickness of thread is $0.4-0.6 / 0.7-0.8 \mathrm{~mm},{ }^{5}$ the count is 12-14 threads in warp and 7-8 in weft and the angle of twist varies between $24^{\circ}-30^{\circ} / 34^{\circ}-37^{\circ}$. There is a weaving error in two pieces in the form of a double thread (Fig. 6:1,2) and some traces after cutting too (Fig. 6: 4). Pieces D-F are denser and originally must have belonged together too, as they show the same features, having thickness of threads $0.5-0.6 \mathrm{~mm}$ in warp and $0.7-0.8 \mathrm{~mm}$ in weft, thread count of $12-14 / 12-13$ and the angle of twist $29^{\circ}-35^{\circ} / 37^{\circ}$. A piece of textile from no. 388 consists of threads $0.8 / 0.6 \mathrm{~mm}$ thick, thread count of 9/10-12 and angle of twist of $30^{\circ} / 31^{\circ}$.

Even though we do not know the find context, the anklet and the textile inside can be dated to the LTB2 and assigned to a female inhumation grave. Moreover, the textile fragments from these anklets show the same features as the comparable material from the eastern part of central Europe, where tabbies made of simple z-spun threads are predominant in this period (Belanová-Štolcová 2012, 314-322; Belanová-Štolcová/Grömer 2009, 10, 11; Bender Jorgensen 1992, 135; 2005, fig. 1; Grömer 2012, 44-47; Grömer et al. 2019; Stöllner 2005, 161).

\section{RECONSTRUCTION OF THE DRESS}

The NHM Vienna has a long tradition in experimental archaeology. In the last decades there has also been a focus on the reconstructions of prehistoric garments, both for textile research (e.g. Grömer/Rösel-Mautendorfer/Bender Jorgensen 2013), as well as for various educational activities of the museum. For the reconstruction of a representative Celtic woman's dress, Karina Grömer selected for

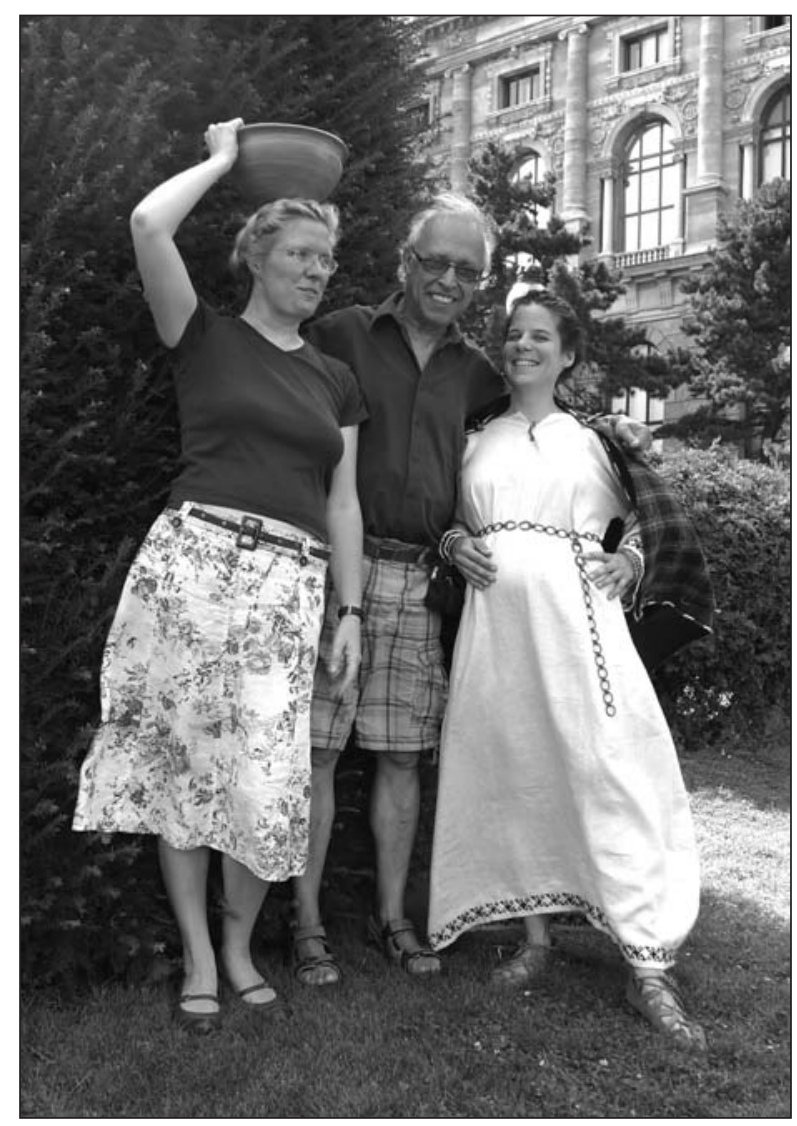

Fig. 7. Slovak-Austrian team documenting the reconstruction of La Tène Period dress at the Natural History Museum in Vienna, based on Nové Zámky find - from left to right: K. Grömer, K. Pieta and T. Štolcová, June 2011 (archive T. Štolcová, reconstruction by K. Grömer).

\footnotetext{
5 In small fragments without a selvedge it is hard to differ between warp and weft threads. Therefore, we take over the method of L. Bender Jørgensen $(1986,288)$, who attributes a higher number of threads to the warp and a lower to the weft. The set of threads is indicated by a 'slash', where the first number indicates the warp and the second number the weft thread. The same applies to the thread thickness, the direction of spin and the angle of twist.
} 


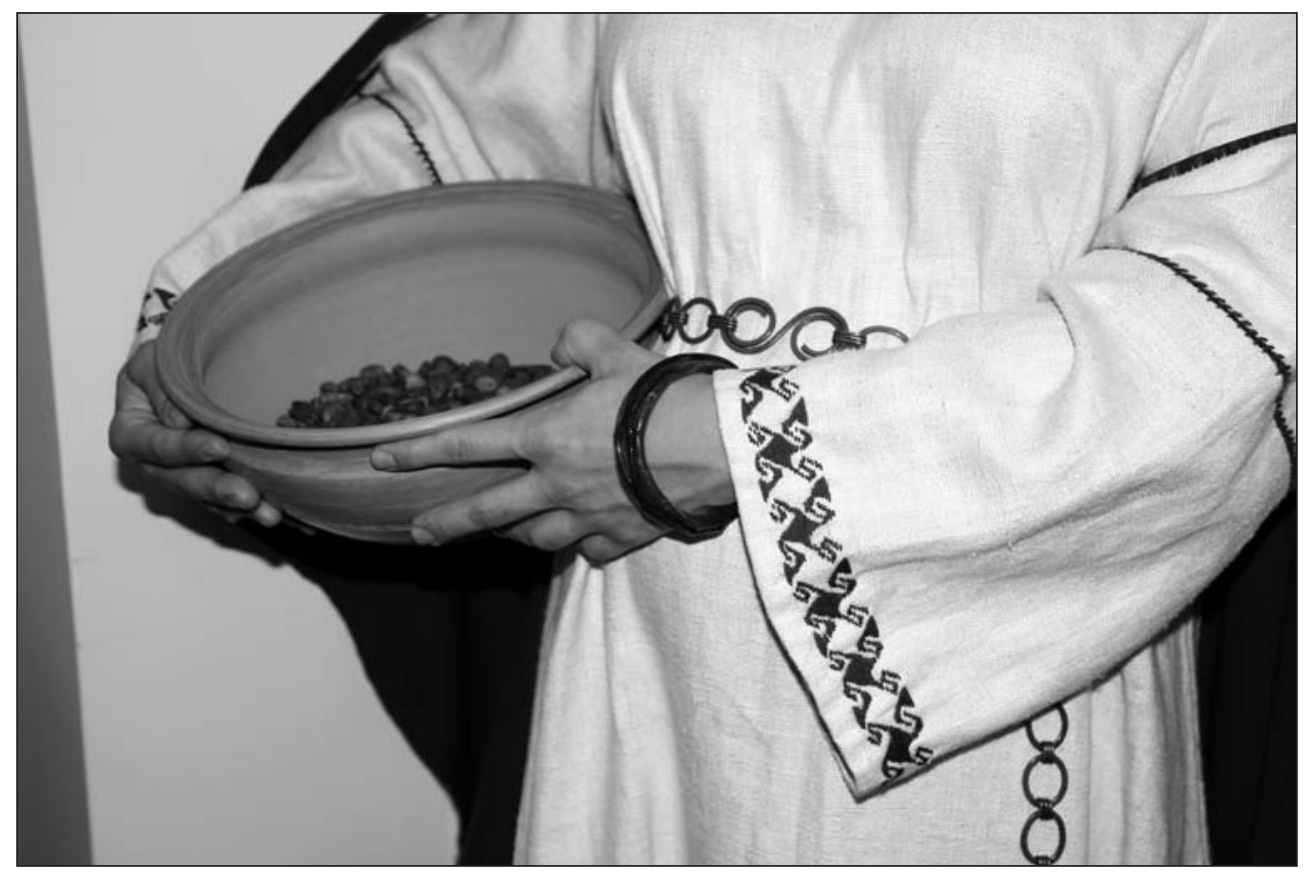

Fig. 8. Detail of the dress in Fig. 7, Nové Zámky embroidery (photo K. Pieta, reconstruction by K. Grömer).

the basic textile design the famous embroidered fabric from Nové Zámky (Fig. 7; 8).

The overall reconstruction and silhouette of the dress is based on diverse pictorial sources, especially from the works of situla art (Lucke/Frey 1962; Turk 2005), as the 'pure' La Tène Period design is more abstract and clearly recognisable dress elements are difficult to obtain (Bagley 2014). In situla art, men and women (seldomly children) are depicted in different garments - both in civil festive garments and in military outfits. Women's clothing is typically depicted in the form of long dresses that reach up to the calves, combined with veils of various lengths (Situla Vače: Lucke/Frey 1962, pl. 73). These dresses often have half-length sleeves, the hems are curved or straight and sometimes decorated with braids. The dress is sometimes gathered around the waist with a belt.

In order to reconstruct clothing from the Early La Tène Period using this evidence, the position of the artefacts in the graves is important. By their position, these are the functional elements of the interplay between garment and dress accessories and jewellery: for example, a belt in a functional position in the pelvic area indicates that it held a belted garment; fibulae found in the shoulder area indicate that fabrics of garments have been stitched together in the upper body area. This information from the graves supplements the pictorial sources.

This way, a wealthy Celtic woman from present Austria and Slovakia was reconstructed in a beau- tiful white linen A-shaped dress. It was decorated with the 'Nové Zámky embroidery' on the sleeves and the lower hem. To hold the garment in place, a chain belt was used. As usually two small fibulae were found in the upper body area, we decided to add a green mantle whose quality and colour reflect evidence from the Dürrnberg saltmines (Stöllner 2005).

\section{THE IMPACT OF TEXTILES ON THE VISUAL APPEARANCE}

The significance of clothing and textiles for the expression of identity and prestige in prehistory cannot be underestimated, being a distinctive factor of non-verbal communication (e.g. Grömer 2016; Sommer 2012; Sørensen 1997; Wells 2008). Garments not only protect against heat, cold and wet weather conditions. In a social meaning, garments are important medium to communicate identities, gender, age, group membership and social status.

It is interesting to look at the visual qualities (textures, colours, patterns, weave types) which were created in textiles in the $1^{\text {st }}$ millennium BC, and what might have been their impact on society. Especially the Nové Zámky textile with its remarkable embroidery gives us some clues, showing the way in which textiles were used as a code to reflect particular social and aesthetic values. New theories in textile research also discuss the visibility of textile structures and pattern types from different 
vantage points: what can be seen from far away and from nearby (see also Grömer 2017)? This poses questions about the proximity of interaction among members of different social groups. Who was able to come near enough to an elite person wearing a sophisticated and 'expensive' textile to see effects that can only be seen from nearby (such as spin patterns on a find from Hochdorf in the form of small-scale houndstooth checks in woad blue and red dyed with an insect dye - c.f. Banck-Burgess 2012)? In this, the Nové Zámky embroidery plays an interesting role, as it has been carried out in bright red on white linen ground - so widely visible. This illustrates that Iron Age textiles of Central Europe defined and expressed a 'social space', group relationships, and demonstrated visual codes of the society.

\section{CONCLUSIONS}

Karol Pieta is an exceptional personality in Slovak archaeology. He incorporates multidisciplinary knowledge into his reflections on archaeological textiles. For example, he will make an archaeological find available to an ethnologist to help reveal connections with younger cultural expressions. It is a pleasure for us to enter such a rare dialogue with people from different disciplines. In this dialogue, the topics have already gone beyond the framework of textiles. Consequently, Juraj Zajonc was invited to make a technological and functional analysis of a bast container and several wooden finds from the princely tomb in Poprad-Matejovce, dated to the end of the $4^{\text {th }}$ c. AD (Fig. 9). Tereza Štolcová has been cooperating with Karol Pieta on this unique find from the very beginning. This great adventure, which began for her at the archaeological research in Poprad in 2006 and continued with the processing of textile and leather finds in Schleswig, Germany, they will conclude together in 2022 as the authors of

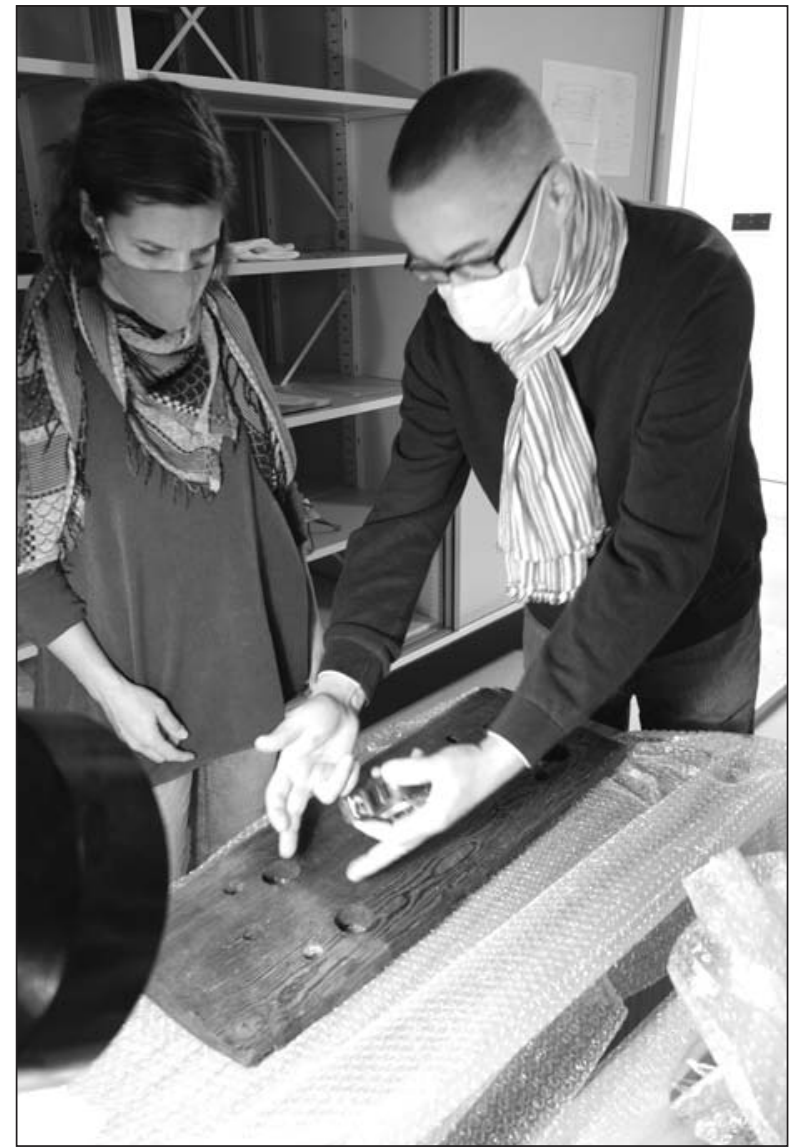

Fig. 9. J. Zajonc and T. Štolcová examining wooden stool from Poprad-Matejovce in the archives of the Institute of Archaeology SAS in Nitra, November 2020 (photo K. Pieta).

the exhibition 'The Prince of Poprad and His Tomb' at the Podtatranské múzeum in Poprad. However, the journey of getting to know the history of textiles will continue, and all three of us are looking forward to new challenges in textile archaeology, greatly in debt to the foundations laid out in Slovakia by Karol Pieta.

\section{BIBLIOGRAPHY}

Bagley 2014 - J. M. Bagley: Zwischen Kommunikation und Distinktion. Ansätze zur Rekonstruktion frühlatènezeitlicher Bildpraxis. Vorgeschichtliche Forschungen 25. Rahden/ Westf. 2014.

Banck-Burgess 1999 - J. Banck-Burgess: Hochdorf IV. Die Textilfunde aus dem späthallstattzeitlichen Fürstengrab von Eberdingen-Hochdorf (Kreis Ludwigsburg) und weitere Grabtextilien aus Hallstatt- und latènezeitlichen Kulturgruppen. Forschungen und Berichte zur Vor- und Frühgeschichte in Baden-Württemberg 70. Stuttgart 1999.

Banck-Burgess 2012 - J. Banck-Burgess: Case Study: the Textiles from the Princely Burial at Eberdingen-Hochdorf, Germany. In: M. Gleba/U. Mannering (eds.): Textiles and textile production in Europe. From Prehistory to AD 400. Ancient Textiles Series 11. Oxford 2012, 139-150.

Belanová 2005a - T. Belanová: The State of Research of La Tène Textiles from Slovakia and Moravia. In: Bichler et al. 2005, 175-189.

Belanová $2005 b$ - T. Belanová: Určenie textilných zvyškov. In: J. Čižmářová: Keltské pohřebiště v Brně Maloměřicích. Pravěk. Supplementum 14. Brno 2005, 65-74.

Belanová/BirkušoválZajonc 2005 - T. Belanová/S. Birkušová/ J. Zajonc: Dva príklady rekonštrukcie na základe archeologického nálezu: výšivka a paličkovaná čipka. In: M. Kotorová-Jenčová (zost.): Experimentálna archeológia a popularizácia archeologického bádania v múzejnej a školskej 
praxi. Zborník referátov z konferencie, Hanušovce nad Toplou. Hanušovce nad Toplou 2005, 123-148.

Belanová/HarmadyoválZajonc 2005 - T. Belanová/K. Harmadyová/J. Zajonc: Devín: experimentálna rekonštrukcia snovadla a krosien v doby laténskej. In: M. Kotorová-Jenčová (zost.): Experimentálna archeológia a popularizácia archeologického bádania v múzejnej a školskej praxi. Zborník referátov z konferencie, Hanušovce nad Toplou. Hanušovce nad Toplou 2005, 105-122.

Belanová-Štolcová 2009 - T. Belanová-Štolcová: Analýza textilných zvyškov z Holubic a Křenovic. In: J. Čižmářová: Keltská pohřebiště z Holubic a Křnenovic. Pravěk. Supplementum 19. Brno 2009, 36-44.

Belanová-Štolcová 2012 - T. Belanová-Štolcová 2012: Slovak and Czech Republics. In: M. Gleba/U. Mannering (eds.): Textiles and textile production in Europe. From Prehistory to $A D$ 400. Ancient Textiles Series 11. Oxford 2012, 306-331.

Belanová-Štolcová/Grömer 2009 - T. Belanová-Štolcová/ K. Grömer: Loom-weights, Spindles and Textiles - Textile Production in Central Europe from the Bronze Age to the Iron Age. In: E. B. Andersson Strand/M. Gleba/ U. Mannering/Ch. Munkholt/M. Ringgard (eds.): North European Symposium for Archaeological Textiles X, 13.-18. 5. 2008 in Copenhagen. Ancient Textiles Series 5. Oxford 2009, 9-20.

Bender Jørgensen 1986 - L. Bender Jørgensen: Forhistoriske textiler i Skandinavien. Prehistoric Scandinavian Textiles. Nordiske Fortidsminder. Serie B, 9. Købehavn 1986.

Bender Jørgensen 1992 - L. Bender Jørgensen: North European Textiles until AD 1000. Aarhus 1992.

Bender Jørgensen 2005 - L. Bender Jørgensen: Hallstatt and La Tène Textiles from the Archives of Central Europe. In: Bichler et al. 2005, 133-150.

Bichler et al. 2005 - P. Bichler/K. Grömer/R. Hofmann-de Keijzer/A. Kern/H. Reschreiter (eds.): Hallstatt Textiles: Technical Analysis, Scientific Investigation and Experiment on Iron Age Textiles. British Archaeological Reports International Series 1351. Oxford 2005.

Bujna 2004 - J. Bujna: K problematike birituality u Keltov. Študijné zvesti AÚ SAV 36, 2004, 321-338.

Bujna 2005 - J. Bujna: Kruhový šperk z laténskych ženských hrobov na Slovensku. Nitra 2005.

Furmánek/Pieta 1985 - V. Furmánek/K. Pieta: Počiatky odievania na Slovensku. Dávnoveké umenie Slovenska 19. Bratislava 1985.

Grömer 2012 - K. Grömer: Austria: Bronze and Iron Ages. In: M. Gleba/U. Mannering (eds.): Textiles and textile production in Europe. From Prehistory to AD 400. Ancient Textiles Series 11. Oxford 2012, 306-331.

Grömer 2016 - K. Grömer: The Art of Prehistoric Textile Making. The development of craft traditions and clothing in Central Europe. Veröffentlichungen der Prähistorischen Abteilung 5. Vienna 2016.

Grömer 2017 - K. Grömer: Textiles as Early Iron Age prestige goods - a discussion of visual qualities. In: R. Schumann/S. van der Vaart-Verschoof (eds.): Connecting Elites and Regions. Perspectives on contacts, relations and differentiation during the Early Iron Age Hallstatt C period in Northwest and Central Europe. Leiden 2017, 221-236.

Grömer et al. 2019 - K. Grömer/P. Ramsl/K. WiltschkeSchrotta/J. Wollmann: Latènezeitliche Gräber aus Schrattenberg mit "Torques" und Textil. Annalen des Naturhistorischen Museums Wien. Serie A 121. 2019, 5-33.
Grömer/Rösel-Mautendorfer/Bender Jørgensen 2013 - K. Grömer/H. Rösel-Mautendorfer/L. Bender Jørgensen: Visions of Dress. Recreating Bronze Age Clothing from the Danube Region. Textile 11/3, 2013, 218-241. DOI: https://doi.org/10.2752/175183513x1379321037403

Hundt 1961 - H.-J. Hundt: Neunzehn Textilreste aus dem Dürrnberg in Hallein. Jahrbuch des Römisch-Germanischen Zentralmuseums 8, 1961, 7-25.

Hundt 1974 - H.-J. Hundt: Die Textilreste aus den Gräbern vom Dürrnberg. In: F. Moosleitner/L. Pauli/E. Penninger: Der Dürrnberg bei Hallein II. Münchner Beiträge zur Vor- und Frühgeschichte 17. München 1974, 136-142.

Hundt 1978 - H.-J. Hundt: Beobachtungen zur Herstellung Frühlatènezeitlicher Hohlarmringe vom Dürrnberg. In: L. Pauli: Der Dürrnberg bei Hallein III/2. Münchner Beiträge zur Vor- und Frühgeschichte 18. München 1978, 619-623.

Hundt 1987 - H.-J. Hundt: Vorgeschichtliche Gewebe aus dem Hallstätter Salzberg. Jahrbuch des RömischGermanischen Zentralmuseums Mainz 34, 1987, 261-269.

Kostelníková 2002 - M. Kostelníková: Laténské nánožníky s textilní výplní z Miroslavi (okr. Znojmo) a Mušova (okr. Břeclav). Přehled výzkumů 43, 2002, 325, 326.

Lucke/Frey 1962 - W. Lucke/O.-H. Frey: Die Situla in Providence. Römisch-Germanische Forschungen 26. Mainz 1962.

Müllauer/Ramsl 2007 - N. Müllauer/P. Ramsl: Herstellungstechnische Untersunchungen an Hohlblechreifen aus dem Latènezeitlichen Gräberfeld von Mannersdorf am Leithagebirge, Niederösterreich. Archäologisches Korrespondenzblatt 37, 2007, 67-84.

Pieta 1992 - K. Pieta: Keltische Textilreste mit Stickereien aus Nové Zámky, Südslowakei. In: L. Bender Jørgensen/ E. Munksgaard (eds.): Archaeological Textiles in Northern Europe: Report from the $4^{\text {th }}$ NESAT Symposium 1.-5. May 1990 in Copenhagen. Tidens Tand 5. Copenhagen 1992, $52-65$.

Pieta 1996 - K. Pieta: Liptovská Mara. Včasnohistorickécentrum severného Slovenska. Archeologické pamätníky Slovenska 5. Bratislava 1996.

Pieta 1999 - K. Pieta: Der archäologische Park und die Feuchtschichtengrabung in Liptovská Mara. In: E. Jerem/ I. Poroszlai (eds.): Archaeology of the Bronze and Iron Age: Experimental Archaeology, Environmental Archaeology, Archaeological Parks. Proceedings of the International Archaeological Conference, Százhalombatta, 3-7 October 1996. Budapest 1999, 357-366.

Sommer 2012 - C. M. Sommer: Dress and Identity - A Social Psychologist's Perspective. In: S. Schrenk/K. Vössing/ A. Wieczorek/M. Tellenbach (Hrsg.): Kleidung und Identität in religiösen Kontexten der römischen Kaiserzeit. Publikationen der Reiss-Engelhorn. Museen Mannheim 47. Regensburg 2012, 257-263.

Sørensen 1997 - M. L. S. Sørensen: Reading Dress: The Construction of Social Categories and Identities in Bronze Age Europe. Journal of European Archaeology 5, 1997, 93-114.

Štolcová 2010 - T. Štolcová: Vývoj výroby textilu a odevu v severnom Podunajsku od konca praveku po včasný stredovek. Dizertačná práca. Archeologický ústav SAV Nitra. Nitra 2010. Unpublished.

Štolcová 2011 - T. Štolcová: Analýza zvyškov textilu z okresov Brno-město a Brno-venkov. In: J. Čižmářová: Keltská pohřebiště na Moravě. Okresy Brno-město a Brno-venkov. Brno 2011, 59-70. 
Štolcová 2013 - T. Štolcová: Analýza textilných zvyškov z laténskych hrobov z okresu Vyškov. In: J. Čižmářová: Keltská pohřebiště na Moravě. Okresy Blansko a Vyškov. Brno 2013, 93-107.

Štolcová 2019 - T. Štolcová: Analýza zvyškov textilu z laténskych hrobov v okrese Břeclav a Znojmo. In: J. Čižmářová: Keltská pohřebiště na Moravě. Okresy Břeclav a Znojmo. Brno 2019, 109-129.

Štolcová/Zajonc 2014 - T. Štolcová/J. Zajonc: Rekonštrukcia tkania v dobe halštatskej na základe nálezu tkáčskej dielne z Dunajskej Lužnej. Zborník SNM 108. Archeológia 24, 2014, 59-82.

Štolcová/Zajonc 2015 - T. Štolcová/J. Zajonc: Interdisciplinary reconstruction of weaving on the warp-weighted loom in the Hallstatt Period. In: K. Grömer/F. Prit-

Manuscript accepted 4. 6. 2021

Translated by authors

Mgr. Tereza Štolcová, PhD.

Archeologický ústav SAV

Akademická 2

SK - 94921 Nitra

tereza.stolcova@gmail.com

PD Dr. Karina Grömer

Naturhistorisches Museum Wien

Burgring 7

A - 1010 Wien

karina.groemer@nhm-wien.ac.at chard (eds.): Aspects of the Design, Production and Use of Textiles and Clothing from the Bronze Age to the Early Modern Era. NESAT XII. The North European Symposium of Archaeological Textiles, $21^{\text {st }}-24^{\text {th }}$ May 2014 in Hallstatt, Austria. Archaeolingua Main Series 33. Budapest 2015, 295-307.

Stöllner 2005 - Th. Stöllner: More than Old Rags - Textiles from the Iron Age Salt-mine at the Dürrnberg. In: Bichler et al. 2005, 161-174.

Turk 2005 - P. Turk: Images of Life and Myth. Exhibition Catalogue. Ljubljana 2005.

Wells 2008 - P. S. Wells: Image and Response in Early Europe. London 2008.

Wilson 2017-2018 - K. Wilson: Mensen in Stof. Inzicht BLKVLD Uitgevers 2017-2018, 36-41.

PhDr. Juraj Zajonc, CSc

Ústav etnológie a sociálnej antropológie SAV

Klemensova 19

SK - 81364 Bratislava

juraj.zajonc@savba.sk 
